\title{
Behind Bars: the truth about drugs in prisons
}

\begin{abstract}
The consumption and dealing of drugs has long been a criminal offence, so how are drugs finding their way into prisons that are meant to be secure places of law enforcement? To be able to confront the problem, an in-depth understanding is needed on the current situation of drugs within prisons. This review focuses on three aspects, firstly looking at the main ways drugs are trafficked into prisons, secondly looking at the issues linked to the use of drugs within prisons and finally evaluating what is being done to try to tackle the problem. Drugs find their way into prisons in numerous ways, which causes problems for the prison system. Prison officials need to be able to keep up with the creative and inventive ways inmates are developing to traffic drugs into prisons. A third of prisoners in England and Wales claimed it was easier to get hold of drugs in prison than it was outside. This undermines prison security and creates problems with violence together being linked with reoffending. Two in five prisoners in England and Wales are known to commit offences in order to get funds to purchase drugs. Health risks are created by inmates sharing syringes, leading to the transmission of infectious diseases. This in turn causes the costs of treatments and detection methods to spiral out of control. Governments are constantly trying to proactively find ways to tackle drugs in prison; these include the use of sniffer dogs and employing more thorough searches by staff. But more needs to be done to eradicate drugs completely.
\end{abstract}

Volume 5 Issue 3 - 2017

\author{
Andrew O'Hagan, Rachel Hardwick \\ Department of Science and Technology Nottingham Trent \\ University, UK
}

\begin{abstract}
Correspondence: Andrew OHagan, Department of Science and Technology, Nottingham Trent University, Nottingham, UK, Tel 44| I5-8483 I53,Email andrew.ohagen@ntu.ac.uk
\end{abstract}

Received: September 03, 2017 | Published: September 14, 2017

Keywords: drugs, prisons, trafficking, law-enforcement, governments

Abbreviations: AIDs, acquired immune deficiency syndrome; CSJ, the centre for social justice; DIP, drug interventions programme; HBV, hepatitis B virus; HCV, hepatitis C virus; HIV, human immunodeficiency virus: IDU, intravenous drug users; MDT, mandatory drug test; MoJ, ministry of justice; NPS, new psychoactive substances; OST, opiate substitution treatment; TB, tuberculosis

\section{Introduction}

Research carried out for this review suggests that drugs are rife in prisons worldwide and illicit drug use such as cannabis, heroin and NPS remains endemic. ${ }^{1}$ This review aims to discuss key aspects associated with the use of drugs, predominantly within prisons in England and Wales, to determine routes by which drugs enter prisons, key issues relating to the use of drugs within prisons as well as the efforts being made to create safer, drug free institutions. The exact extent of the drugs problem in prison is not currently known, as individual institutions rarely exchange information relating to their internal drug markets. ${ }^{2}$ Speculative figures, however, estimate that 75,000 drug users pass through the prison system in England and Wales every year. ${ }^{3}$

Figures from the MoJ, as of $30^{\text {th }}$ September 2016, state that the prison population in England and Wales was 85,639, which equates to $0.84 \%$ of the conservative estimate of 10.2 million people Dolan et al.,5 indicate as the global penal population., ${ }^{4,5}$ Drug use and dependence vary worldwide from $10 \%$ to $48 \%$ among male inmates and $30 \%$ to $60 \%$ among female inmates. ${ }^{1,6-8}$ Figure 1 shows the proportion of prisoners in England and Wales $(n=10,702)$, with problems with illicit substances. ${ }^{1}$ A 1998 study found that $75 \%$ of prisoners in England and Wales had, at taken illegal drugs whilst in prison. Of inmates canvassed at HMP Birmingham and HMP Preston, $17 \%$ and $13 \%$ respectively reported that they had developed a drug addiction whilst in prison. 6,9

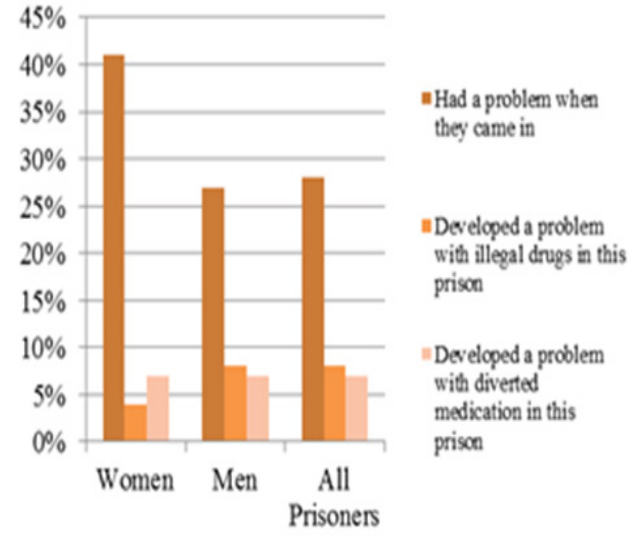

Figure I The proportion of prisoners in England and Wales between April 2014 and August 2015 having problems with illicit substances. It may therefore be that drug users continue a habit that they had already acquired before going to prison, as suggested by Figure I Reconstructed from Roberts, 2015. ${ }^{9}$

Figure 2 shows the prevalence of the type of drug use among inmates in European countries, the United Kingdom being in the top four countries for each type of drug..$^{10}$ Research suggests that drugusing inmates dictate the daily routine in prisons. This includes drug treatment programmes and control measures aimed at preventing drug trafficking and violence. ${ }^{11}$ Prisons become an effective vehicle for spreading drug use because it is easy for drug users to establish social relationships and pass on their drug habit, due to peer pressure and power of association. The main reasons for using drugs in prisons are reportedly, to relieve insomnia, boredom (due to a lack of constructive activities) and as a coping mechanism. ${ }^{11-14}$ Drug using prisoners generally experience deprivation, poor education achievements together with unemployment issues, which inevitably lead to poor housing. ${ }^{13}$ 


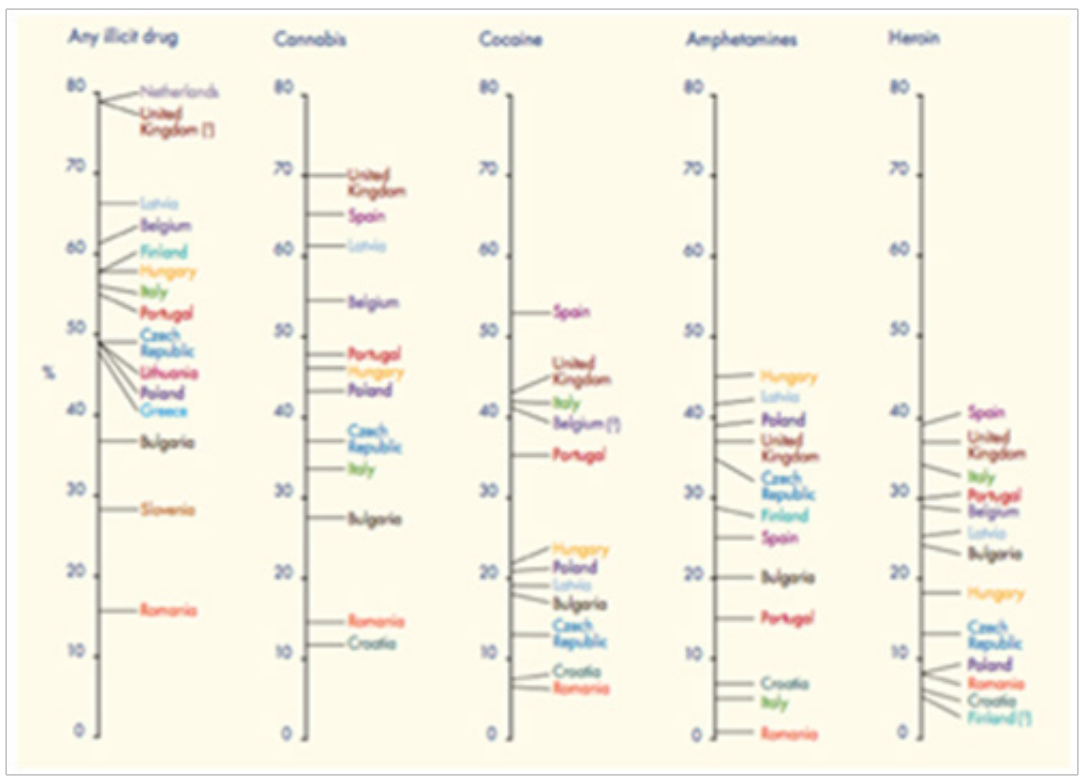

Figure 2 Lifetime prevalence (\%) of illicit drug use among inmates in European countries. ${ }^{10}$

Of 86 subjects from two institutions in India, $83(97 \%)$ reported that drugs were available in their prison and $56(65 \%)$ used drugs whilst in prison. ${ }^{8}$ With a third of all prisoners in England and Wales claiming that it was easy to get hold of illegal substances whilst in prison, to the extent that prisoners claimed it was easier to get hold of drugs in prison than it was outside. ${ }^{15,16}$ In Oakwood prison, in Staffordshire, it was said by inmates, that drugs were easier to obtain than soap and in Brixton prison, London, Officers' uniforms smelt of 'skunk', a strong herbal form of cannabis that consists of buds, because it's use was so widespread. ${ }^{17,18}$ Table 1 illustrates the prevalence of lifetime drug use and drug use in prison. The information is from a sample of 3142 inmates across all operational prisons in England and Wales in 1995. Although the number of prisoners who had used cannabis was greater than those using heroin, the percentage that used both was around $60 \% .^{19}$

Table I Prevalence of lifetime drug use and drug use in prison reconstructed from Boys et al ${ }^{19}$

\begin{tabular}{lllll}
\hline Drug Type & Frequency (\% of total) & $\begin{array}{l}\text { Ever used in prison } \\
\text { (\% of all users) }\end{array}$ & $\begin{array}{l}\text { Initiated use in } \\
\text { prison (\% of all } \\
\text { users) }\end{array}$ & $\begin{array}{l}\text { Initiated use in prison } \\
\text { (\% of those used in } \\
\text { prison) }\end{array}$ \\
\hline Cannabis & $24 I I(76.7)$ & $1538(63.8)$ & $154(6.4)$ & 10 \\
Amphetamines & $1529(48.7)$ & $216(14.1)$ & $36(2.4)$ & 16.7 \\
Cocaine/ Crack & $1442(45.9)$ & $351(24.3)$ & $134(9.3)$ & 38.2 \\
Heroin & $1203(38.3)$ & $743(61.8)$ & $318(26.4)$ & 42.8 \\
Injecting drug use & $818(26.0)$ & $130(15.9)$ & $33(4.0)$ & 25 \\
\hline
\end{tabular}

\section{Discussion}

\section{How do drugs get into prisons?}

Drug routes into prisons are numerous, varied and likely to differ from prison to prison. ${ }^{9}$ They often require sophisticated planning and preparation, to circumvent systems put in place to prevent drug smuggling. ${ }^{20}$ It has been stated, by a prison officer, that prisoners could be inventive and creative in the ways of bringing in drugs, which makes the task of security management increasingly difficult. ${ }^{3}$ Drugs are disguised in a variety of ways, which includes trying to disguise the smell, for example by smothering the package with marmite. ${ }^{15}$ Synthetic cannabis, sprayed onto paper that is smoked, is often difficult to detect. ${ }^{9}$ The different ways drugs enter prisons are detailed below.

\section{Visitors}

A common way that drugs find their way into prisons is through visitors. They pass the contraband to prisoners during visits using diverse methods. This does not necessarily mean visitors willingly take items into prisons, with some being coerced and put under pressure by third parties., ${ }^{9,21}$ It has been confirmed by staff, as well as prisoners, that prison visits are one of the more usual routes for drugs to enter the prison system. ${ }^{3}$ In England, there has been an increase in visitors being arrested on suspicion of conveying drugs. According to CSJ research, there were 300 cases in 2013/14, an increase of $10 \%$ in three years. ${ }^{6,15}$ Approximately 5\% of inmates reported that, during family visits, a family member would smuggle in substances for them. ${ }^{8}$ A good example is the case of Charlotte Millward, a 35-yearold mother of two, who was seen reaching inside her undergarments 
and handing 10 tablets to her boyfriend during a visit at Holme House Prison in 2014. The tablets, worth around $£ 2$ each outside of prison, were worth $£ 40$ inside the prison. For this offence, Charlotte received a six-month suspended prison sentence. ${ }^{15}$ In other examples, an exinmate told how he asked his sister to send heroin sewn into the hem of a towel, drugs have been packaged in balloons so they can be swallowed and a lawyer was caught carrying drugs in the sole of their shoes. ${ }^{16,17,22,23}$ There have also been instances of visitors concealing drugs wrapped in cling film in body orifices, in baby's nappies or that have been passed to the prisoner in crisp packets, drinks cans or cups of tea. ${ }^{17,23}$

Deliveries can be made by a handshake, a 'sloppy kiss' (passing drugs from the visitor to the inmate via the mouth), and even simply passing goods over the table. ${ }^{16,20}$ In some cases, drugs enter prisons through the prisons' various operations systems, including food and other goods as well as prisoners' correspondence and packages. ${ }^{9}$ In Canada, the Union of Canadian Correctional Officers state that if a visitor tests positive for the presence of controlled drugs they only very rarely notify the police. Generally, the visitor is sent away, is allowed to visit without any physical contact or has to undergo a strip search. $^{24}$

\section{Over prison walls}

In large training institutions with long perimeters and relatively free prisoner movement, it is possible for small packages containing drugs to be thrown over walls or fences. These are subsequently collected by inmates who use illicit mobile phones smuggled into the facility to co-ordinate the collection. ${ }^{3,9,23}$ Inmates will often stage some form of distraction, such as an argument or fight, to divert attention from packages being thrown into the facility. Inmates will then crowd around the packages, keeping officers at bay, which gives an inmate tasked with collection the ability to "plug" the drugs, in other words placed in their rectum. ${ }^{16}$

Anecdotally, it has been indicated by a prisoner that they used an illicit mobile phone to inform a friend where to aim and throw a package, where a payment of half an ounce of cannabis was used to bribe an outside wing cleaner to deliver the drugs to an inmate. ${ }^{23}$ A range of everyday items can be used to conceal drugs when they are thrown over fencing. These include tennis balls, arrows and even dead birds such as pigeons. ${ }^{16,17,21}$ Larger packages present more of a challenge, however the more determined have developed makeshift catapults to help put packages over fences and walls, see Figure 3. In a recent incident, where hundreds of steroid pills and painkillers packed into Ribena cartons were thrown over the walls by two brothers, it was found that a shortage of staff meant that insufficient checks were being carried out to search exercise yards and perimeters for packages that had been catapulted in or dropped by drones..$^{15,25}$

More recently, as technologies have advanced, a growing number of cases have occurred where packages were "dropped-in" by drones, see Figure 4, in a similar manner to the parcel delivery systems being developed by some commercial companies, such as Amazon. ${ }^{9}$ The use of drones for drug trafficking purposes has increased from no known or reported incidents in 2013, 2-incidents in 2014 and 33-incidents in 2015 , an increase of $100 \%$. Their current growth in popularity can perhaps be attributed to the large payloads, consisting of drugs and other contraband they can carry and deliver in a single flight. With good planning, coordination and timing, a delivery can be made without those involved being caught. Figure 5 shows the significant amount of drugs and contraband intercepted by law enforcement officers from the drone subject of Figure $4 .{ }^{26}$
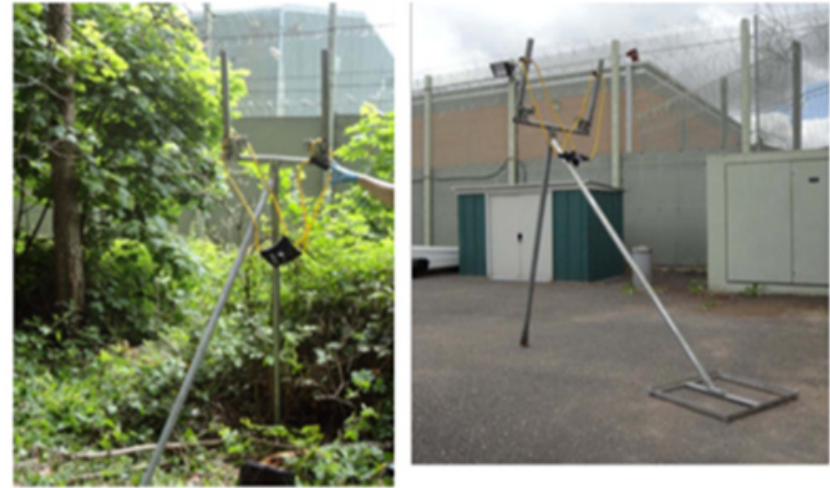

Figure 3 A catapult that was found outside a prison fence. It was used to launch contraband into the prison. ${ }^{9}$

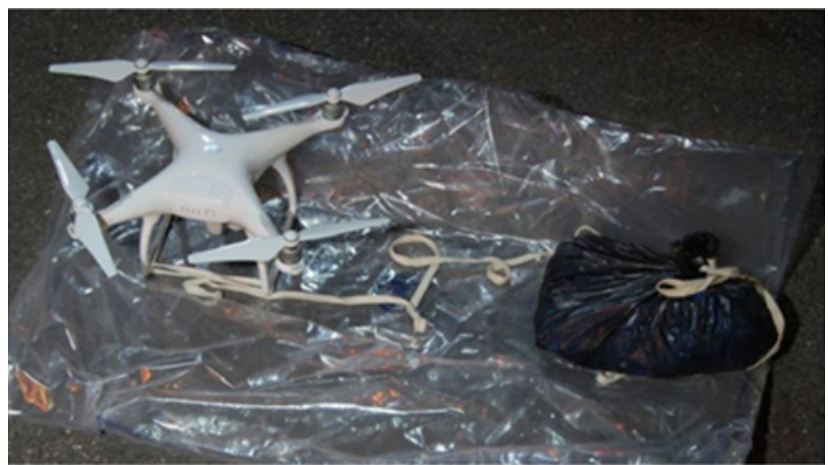

Figure 4 Drone carrying large amounts of drugs and mobile phones that was intercepted by police close to HMP Pentonville. ${ }^{26}$

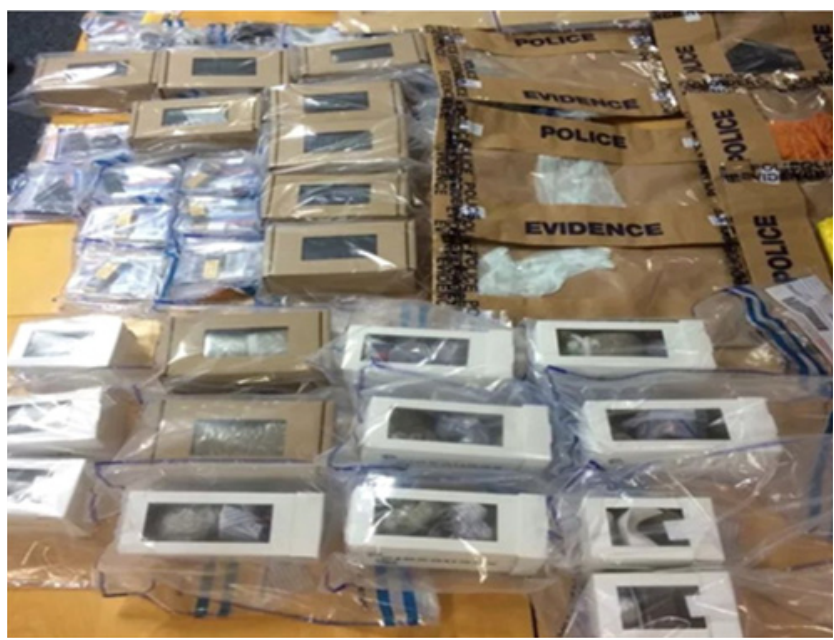

Figure 5 Drugs and mobile phones that were being carried by the drone in figure $4 .{ }^{26}$

\section{New or returning prisoners}

Another route for drugs to enter into prisons is via newly convicted or returning prisoners. In this area, according to MoJ figures, the number of drug seizures between 2011 and 2014 increased by $18 \%$ from a reported 3,700 in 2011 to almost 4,500 in 2014. ${ }^{15}$ In busy prisons, drugs are taken in by prisoners moving between court and prison. In some instances, prisoners will intentionally seek to get 
themselves recalled to court so they can smuggle drugs into prison on their further return. ${ }^{9}$ Inmates, in some cases reported that internal physical searches are unlikely, giving suppliers the confidence that their drugs are unlikely to be detected. ${ }^{20}$ In other instances, inmates have indicated that searches on re-entry are comprehensive. As such, they would need to adapt, often meaning that inmates would have to hide drugs within body cavities. One inmate reported that it was no secret that everyone brought drugs into prison using the plug approach. ${ }^{6,21,27}$ In January 2015, custody staff found 20 ecstasy tablets in the waistband of tracksuit bottoms, bags of cannabis sewn into the lining of underwear and in the trainers of a man convicted with firearms offences..$^{15}$ Once inside, inmates act as enterprise distributors, selling and distributing drugs, their incentive being drugs free of charge. ${ }^{20}$ When locked in their cells, inmates create makeshift ropes known as 'lines' to pass drugs between cell windows. ${ }^{16}$ Prisoners also divert legally prescribed medication, they sip the medication in front of the nurse and will later spit it out into a cup to give or sell to other inmates. ${ }^{16,17}$

\section{Post}

During 2013/14 in England, there were 349 incidents where drugs were discovered in prison post. ${ }^{6,15}$ This is because not all letters are scanned, when one institution allowed inmates to receive Christmas cards there was an increase of drugs in the prison. ${ }^{17}$ In a Scottish Prison, inmates are no longer allowed to receive their children's artwork or drawings after an incidence when powdered Valium was found in the paint. Staff at HMP Shotts in Lanarkshire found the Valium had been painted onto the artwork which inmates would cut up and eat ${ }^{15,28}$ (Figure 6).

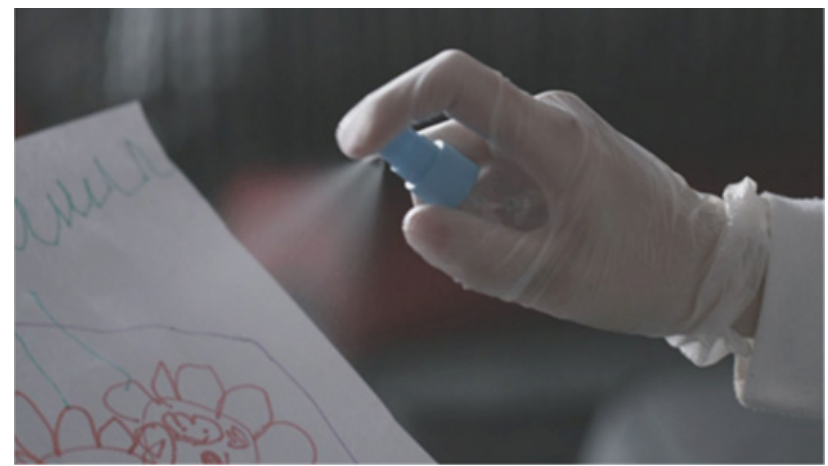

Figure 6 Spice can be sprayed on to children's drawings and then smoked. It is not detectable by $x$ ray and cannot be smelt. Inside prison, one sheet is worth approximately $£ 50 .^{28}$

\section{Corrupt prison staff}

One of the more worrying ways drugs enter prisons is by corrupt prison staff, whether this is guards, nurses, trainers, suppliers or prison tutors, as searches and sniffer dogs are rarely used on staff., ${ }^{9}, 16$ Table 2 shows the increase in convicted staff in England (Table 2). The number of prison staff convicted, dismissed and excluded, due to conveying drugs into prisons in England, from April 2011 to March 2014. Reconstructed from Roberts, $2015 .{ }^{9} \mathrm{~A}$ prison tutor was caught trying to smuggle $£ 10,000$ worth of cannabis and heroin to a convicted drug dealer. ${ }^{15}$ In Rouhmieh, inmates and prison staff were charged for allegedly forming and operating a drug trafficking ring in Lebanon's largest prison. The staff involved included guards, officers and a doctor who provided each other cover whilst distributing the drugs to inmates. ${ }^{29}$ One prison official said that it was easy to bring drugs into prison, reporting, day staff were searched around once a year and night staff were never searched. ${ }^{6}$

Table 2 The number of prison staff convicted, dismissed and excluded, due to conveying drugs into prisons in England, from April 20II to March 2014. Reconstructed from Roberts ${ }^{9}$

\begin{tabular}{lllll}
\hline & $2010 / 11$ & $2011 / 12$ & $2012 / 13$ & $2013 / 14$ \\
\hline Total & 11 & 16 & 9 & 25
\end{tabular}

Staff are enticed by cash bribes; a prison officer received $£ 1000$ for smuggling an ounce of heroin and an ounce of crack cocaine, whilst one officer received $£ 500$ for a package the size of three tennis balls containing anything the inmate wanted, drugs or illicit mobile phones. $^{20,21,30}$ In Georgia, 49 current and former correction officers from 11 prisons were accused of accepting bribes and smuggling contraband into prisons such as drugs and illicit mobile phones. This helped inmates to commit money laundering, identity theft and wire fraud from inside their cell. In addition to smuggling drugs and contraband, the officers were charged with wearing their uniform off duty to protect a drug trafficker, who turned out to be an undercover agent. $^{31,32}$

An inmate from HMP Welling borough reported how an officer could be manipulated and then blackmailed into bringing in contraband and drugs. Firstly, extracting small snippets of personal information that could be used to give the impression of a relationship. Then asking the officer to bring in small items such as biscuits or a magazine, building up to larger items whilst providing a concerned ear for any personal issues they could take advantage of. After reaching a certain stage, the officer is in the position where they cannot refuse without being at risk of disciplinary action because of the infractions they have already committed. ${ }^{23}$ Prison officials have also helped inmates run a $£ 30$ million drug operation from inside their cell. In HMP Wandsworth, a group hacked computers provided by the MoJ, using internet and mobiles phones from prison guards. As a result, $£ 30$ million of illegal drugs ended up on London's street between 2010 and 2013. ${ }^{33}$ The many and varied methods to tackle these issues are discussed later.

\section{Issues facing prisons regarding drugs}

Drug misuse is a severe threat to the security of the prison system, the health of prisoners and the safety of prison staff. The effects can extend outwards to prisoners friends, family and the wider community. ${ }^{9}$ Drugs in prisons undermine prison security; studies show a reciprocal relationship between drug related problems and criminal behaviour., ${ }^{6,34}$ Listed below are some of the main issues associated with the use of drugs within prisons.

\section{Violence}

The link between violence and drugs in prison is well documented and has increased over the years; see Figure $7 .{ }^{35} \mathrm{As}$ well as the impact on the health of inmates, criminals use drugs to make evident their authority within the prison. This results in assaults, blackmail and violence, not just between prisoners, but also against prison employees. ${ }^{24}$ Inmates are said to assault, threaten or pressure staff when drugs are in short supply, caused by enhanced drug enforcement. ${ }^{21}$ Drug trafficking within a prison generates a hierarchy, with inmates 
being forced by stronger, more influential inmates to act as smugglers, couriers and dealers. These inmates are at greater risk, Officers explained. ${ }^{11,21}$ Violence protects the credibility, profits and reputation of their business. ${ }^{20}$ Inmates are hired to accumulate payments and intimidate, threaten and be physically aggressive towards debtors. The level of violence used depends on the amount the debtors owe, with a rising intensity as the debts increase. Typically, the violence would increase from threats and fights to more serious violence involving weapons such as makeshift knives, see Figure $8 .{ }^{20}$

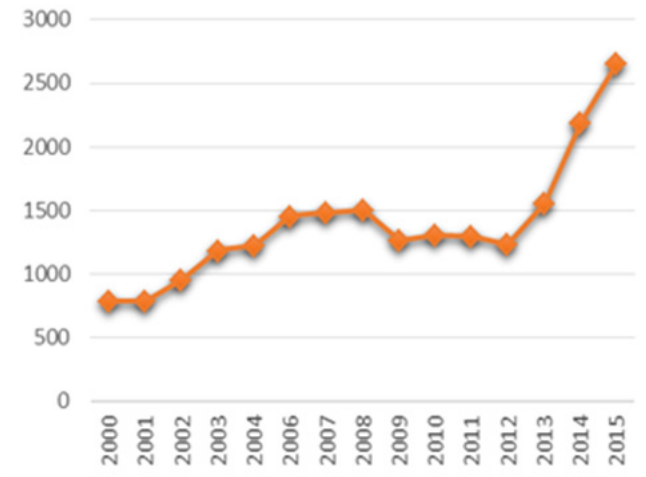

Figure 7 The rise in prison violence between 2000 and 2015 in England and Wales. Reconstructed from Bromley Briefings Summer 2016. ${ }^{35}$

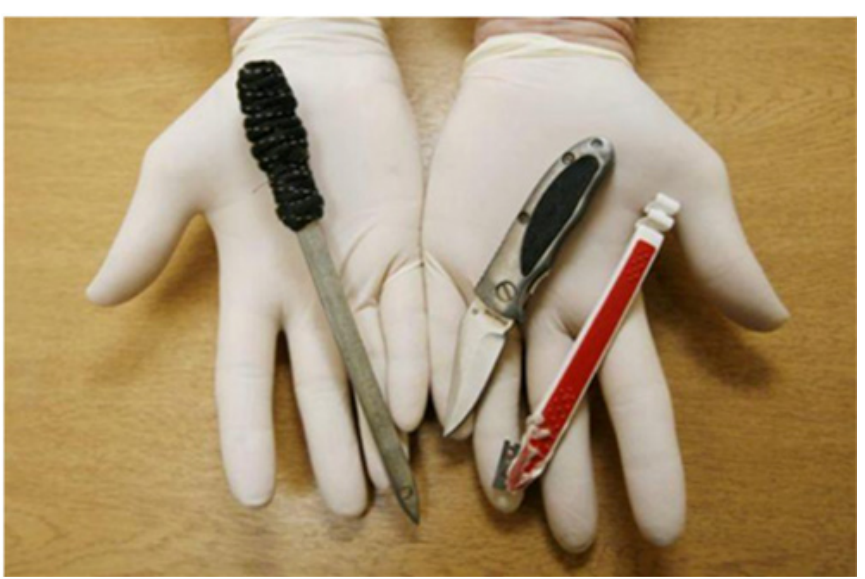

Figure 8 Makeshift weapons seized at HMP Barlinnie in Scotland. ${ }^{38}$

One model that studied status and power in prison settings implies that some prisoners influence other vulnerable prisoners to take drugs to exploit them for financial gains. ${ }^{3}$ There has also been an increase of $20 \%$ in the number of assaults in prison since 1993 to 1995 . The presence of drugs may lead to institutional violence, with inmates who use drugs behaving in aggressive and hostile ways that facilitate violent acts. ${ }^{37}$ If prisoners have paid but not received any drugs, for example if they have been seized by prison officers, they will target the supplier unless he can produce the goods. ${ }^{21}$ Inmates who had received disciplinary actions for possession or use of controlled substances or contraband were 4.9 times more likely to display disruptive violent behaviour than those who did not. ${ }^{1}$

The violence is not just connected to inside prison; it also extends to debts being enforced on the prisoner's friends and families outside prison. Additionally, profits from drug supply in prison may be used to fund criminal activity outside of prison in the community. ${ }^{9}$ Mike
Ike, of the prison governors association, believes that spice (a NPS) is directly linked to increased violence in prisons, creating challenges for prison officers. ${ }^{40}$ An inspection of a private prison in Liverpool found that the availability of drugs and gang issues were a considerable factor for the majority of violence. ${ }^{12}$

\section{Cost}

There are financial costs associated with institutional drug activity. The violence and disruption not only has negative consequences for prisoner and staff wellbeing, it causes the destruction of property and infrastructure. In the United States, the cost of each incident of misconduct carried out by prisoners is in the region of $\$ 1,000$ ( $£ 800)$. This often results in the need for constructing higher security prisons, which will incur more costs. ${ }^{37}$ European countries have an estimated expenditure in the range of $€ 3.7$ billion to $€ 3.9$ billion ( $£ 3.1$ billion) on drug law offenders. ${ }^{2}$ Drug related crime cost England and Wales $£ 13.5$ billion and the CJS budgeted over $£ 300$ million in 2006/07 for adult drug interventions (Figure 8 ) ${ }^{38}$ Specifically, prison treatment in England and Wales has increased from $£ 7$ million in 1997/98 to $£ 80$ million in 2007/08. ${ }^{39}$ On the other hand, it is thought that the cost of institutional OST programmes may be offset by the savings acquired from offenders successfully remaining in the community longer. ${ }^{1}$

\section{Health}

Drugs create severe health issues in prisons, with the total healthcare expenditure for inmates from April 1993 to March 1994 totalling $£ 58.2$ million, which is equivalent to $£ 4.5$ million per 28 days in England and Wales. ${ }^{40}$ The main health care services for drug-using inmates include mental health, HIV treatment and other infectious disease treatment. ${ }^{41}$ Furthermore, drug abuse treatment experts estimated that it costs $£ 100,000$ per annum to run a drugs rehabilitation and reduction programme in a prison with 500 inmates, although this is half the cost of MDT. ${ }^{40}$ A horrifying statistic is that in the week after release from prison, prisoners are approximately 40 times more likely to die than the general public, and more than $90 \%$ of the deaths are drug related. There are still a significant number of deaths in prisons, see Figure 9.

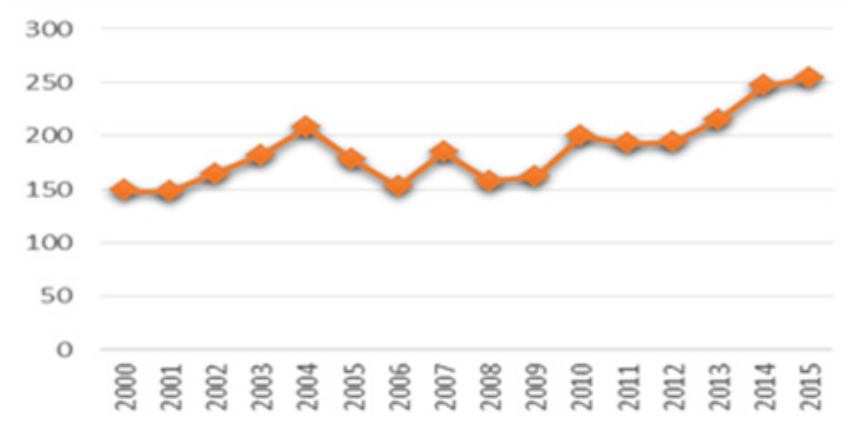

Figure 9 Number of people who died in prison between 2000 and 2015 in England and Wales. Reconstructed from Bromley Briefings Summer 2016. ${ }^{35}$

\section{Treatment programmes}

Treatment programmes were introduced due to the public concern about HIV, AIDS and the apprehension of the spread in prisons due to drug use. ${ }^{34} \mathrm{An}$ international survey in 2009 reported that at least 37 countries offered OST in a community setting but not in a prison setting. ${ }^{1}$ Self-motivation increased the likelihood of success in adult 
prison-based drug treatment programs, which in turn means the cost effectiveness is affected by the attitude of inmates to change. ${ }^{42}$ One issue with drug treatment programmes is the lack of anonymity and the fear of retaliation from other prisoners. ${ }^{34}$ Nevertheless, results show that substitute treatment programmes, especially methadone maintenance treatment can reduce drug use and injecting in institutions. ${ }^{43}$ DIP managed 58,339 class A drug misusing offenders into drug treatment in $2009 / 10 .{ }^{44}$ In 2012/13 there were 193,575 clients aged $18+$ in treatments for 12 weeks or more, $47 \%$ of clients exiting treatment had completed treatment and overcome their dependency, $13 \%$ needed more treatment and $11 \%$ were transferred for further treatment in the community. ${ }^{45}$

\section{HIV/Sharing syringes}

There were 10.2 million people in prisons worldwide on any given day in 2014, it was estimated that 3.8\% had HIV, $15.1 \%$ had $\mathrm{HCV}, 4.8 \%$ had chronic HBV and $2.8 \%$ had TB. Although there was an estimated 10.2 million people incarcerated in any given day, over 30 million individuals transition from prison to the community each year. Because of this, institutions act as incubators to infections as there are higher levels than in the community. Injecting drugs is substantially greater in prisoners, ranging from 2\% to 38\% in Europe and up to $55 \%$ in Australia, in comparison to $0.3 \%$ in Europe and $0.2 \%$ in Australian general populations. ${ }^{5}$ Inmates are at greater risk of contracting diseases due to injecting drug use. In a study of 492 IDUs, $70.5 \%$ reported sharing needles in prison compared to $45.7 \%$ in the month before imprisonment. ${ }^{1,5}$ Failure to provide healthcare, harm reduction programs and the lack of access to clean needles facilitates the transmission of diseases. ${ }^{1,12,19,21}$ The situation is also exacerbated by prison officers confiscating syringes, which limits the number left, increasing the use of shared needles. ${ }^{22} \mathrm{HIV}$ and $\mathrm{HCV}$ is reportedly $15-$ 39 times higher among prisoners than the general population, inmates with HIV may cost the correctional system in the United States at least $\$ 10,000$ a year on top of all other expenses. . $^{13,21,27}$

\section{Prescription drugs}

The abuse of prescription drugs is common in prisons in England and Wales. A survey carried out by the UK MoJ found that buprenorphine diversion was an immense issue. Out of 139 prisons in England of Wales, 87 were analysed and reported that buprenorphine was detected in MDT. It was found to be the most misused drug in 11 prisons and the third most misused drug overall. ${ }^{6}$ It is the duty of nurses and officers to check the mouths of inmates ten minutes after taking prescribed medication to ensure it is not being diverted. However, due to the rising prison population it is widely reported that prison staff are unable to fulfil this duty due to time constraints. ${ }^{1}$ In a Scottish prison, a related pattern of drug distribution was found, a minority of prisoners enrolled in treatment programmes held back their medication to give to fellow inmates with withdrawal symptoms. ${ }^{46}$ Prisoners stored the tablets in their mouths and retrieved them when they got back to their cell, or when prison dispensers were not looking. ${ }^{20}$

Opiate maintenance is over prescribed in prisons with doctors represcribing medication without meeting the patient. There has been an increase of $137 \%$ in opiate maintenance prescriptions in the past 6 years. ${ }^{6}$ Figure 10 shows that maintenance prescriptions are increasing and detoxification treatments decreasing, which is helping the increase of diverted prescription medication. There were 5900 people in prison last year who had become addicted to prescription medication. ${ }^{6} 9 \%$ of prisoners reported that they have had to give prescribed medication away, with $7 \%$ of men and $7 \%$ of women reporting they had developed a problem with diverted medication whilst in prison. ${ }^{35}$

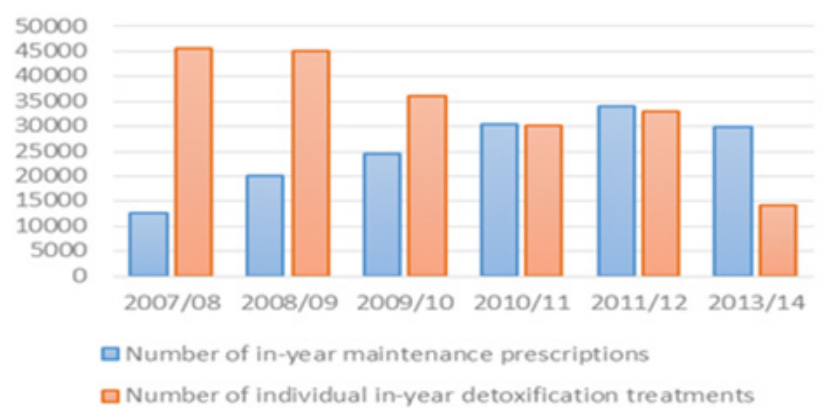

Figure 10 The number of in-year maintenance prescriptions has increased since 2007/08 and the number of individuals in detoxification treatments has decreased. Reconstructed from Drugs in Prison, the Centre for Social Justice. ${ }^{6}$

\section{Re-offending}

Drug use significantly contributes towards reoffending rates, with two in five prisoners in England and Wales saying they commit offences in order to get money to buy drugs. ${ }^{6}$ Reports from HMP Blantyre in 2010/11, found that $41 \%$ of prisoners reported committing offences to get money to buy drugs. One-year conviction rates were more than double for prisoners who used drugs in the four weeks prior to custody $(62 \%)$ compared to prisoners who have never used drugs (30\%). Over half $(57 \%)$ of drug misusing offenders reoffended within a year of release compared to $27 \%$ of all offenders. ${ }^{6}$ Within a year of release from prison, $58 \%$ of heroin users who did not receive any treatment were re-incarcerated compared to $41 \%$ who did receive treatment. ${ }^{1}$ Research has found that the general volume of re-offending of a unit of 7,727 individuals was $26 \%$ lower following identification through positive DIP tests, and approximately half of the unit showed a decline in offending of $79 \%$ in the following six months. ${ }^{44}$

A published prison policy has been introduced to help tackle reoffending by trying to get prisoners off drugs and into work, which included eliminating the drug supply and integrating drug treatment systems with enhanced clinical services. ${ }^{47}$ Inmates who attended treatment programmes were half as likely to be re-arrested one-year post release, compared to inmates who were not treated..$^{42}$ Many of the large number of prisoners who were re-incarcerated for drugrelated parole violations did not receive the treatment they needed and were re-introduced into the community with a high probability of relapse. ${ }^{41}$ The main issue with re-offending is the cost to the economy - between $£ 9.5$ and $£ 13$ billion in $2007 / 08$, with $47 \%$ of adults being reconvicted one year after release. ${ }^{35-48}$

\section{New psychoactive substances}

The availability of NPS, particularly synthetic cannabis (known as legal highs, 'spice' or 'mamba') have become predominant in recent years, see Figure 11, with seizures increasing from 133 in 2012 to 430 in 2014 and then to 851 between October and November 2015.9,35,49,50 With prisoners suggesting that as many as $90 \%$ of prisoners were regularly taking them, the head of substance misuse estimated that the figure was closer to $60 \%{ }^{6} \mathrm{NPS}$ mimic the active ingredients that are found in cannabis and have varying chemical compositions that make the effects unpredictable. ${ }^{6,49}$ NPS have created additional significant problems and are now the most serious threat to the safety and security of the prison system according to the former chief inspector of prisons, Nick Hardwick. ${ }^{9,35}$ 


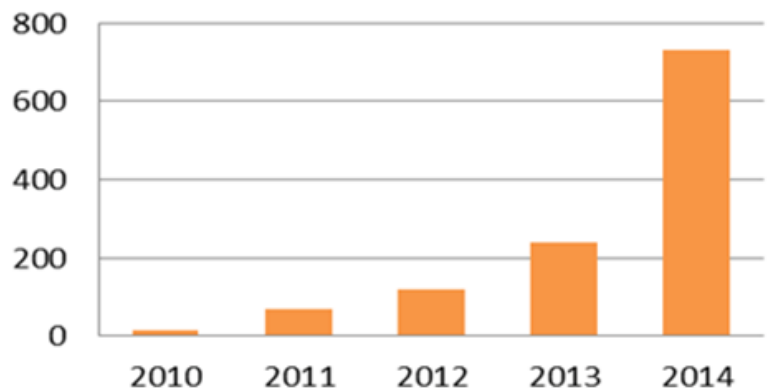

Figure I I Increase of spice seizures in England and Wales from 2010 to 2014. Reconstructed from Drugs in Prison the Centre for Social Justice. ${ }^{6}$

(Figure 12) NPS cannot be detected using current testing methods, they are odourless and the composition changes from batch to batch. ${ }^{9,25} \mathrm{~A}$ report linked 19 prison deaths between 2012 and 2014 with synthetic cannabis, with one incidence of a man who died after smoking a spiked cigarette that he had been given by other inmates who wanted to test a new batch. Inmates whose behaviour was described as exemplary and fun-loving have committed suicide and another inmate had to sell possessions to pay off his debts. ${ }^{9,25}$ The inconsistent composition and unknown effects make the health consequences more concerning and the rising use of legal highs behind bars is linked to more cases of selfharm and assault in jails., ${ }^{9,50}$ At HMP Lindholme, a category $\mathrm{C}$ prison near Doncaster, which holds just over 1,000 adult inmates, more than a kilo (2.2lbs) of legal highs and a dozen mobile phones were seized in a single month, NPS have also been linked to 39 deaths at the prison in 2 years. ${ }^{51}$ In a study carried out by the office of national drug policy and the University of Maryland's centre for substance abuse research in 2013, 33\% of urine samples tested positive for synthetic cannabinoids in Washington DC institution populations. The drug screening used to identify the synthetic cannabinoids is not normally used in the CJS. ${ }^{52}$ It is linked to deaths, serious illnesses and episodes of self-harm among inmates, in a Louisiana prison in 2014, 4 inmates overdosed on synthetic cannabis, they became unresponsive and one was admitted to intensive care. ${ }^{25,52}$

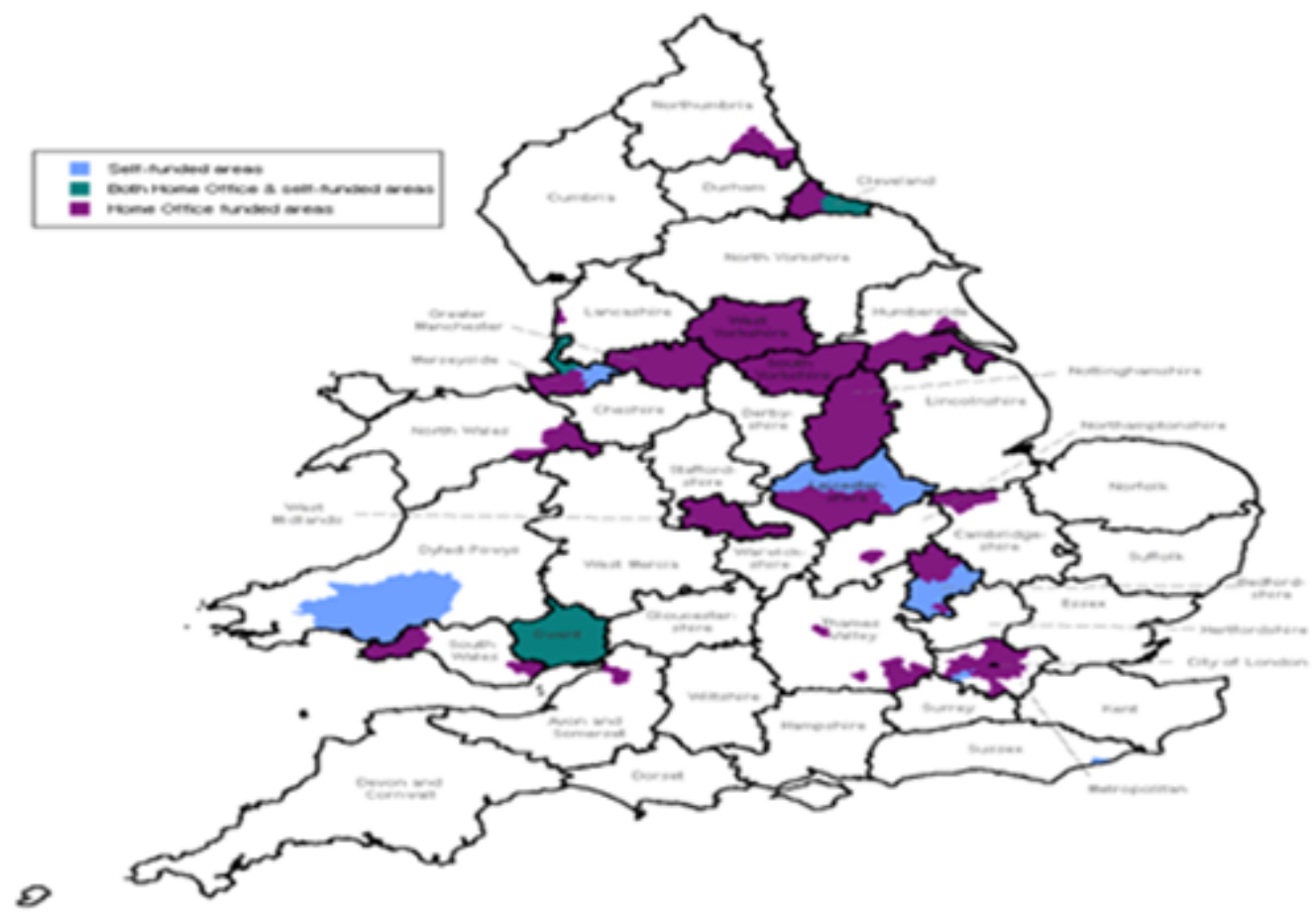

Figure 12 Areas in England and Wales operating drug testing on arrest, April $2011 .{ }^{44}$

\section{Mandatory drug testing}

MDT is one of Government's key strategies, but is unreliable and potentially dangerous. ${ }^{2}$ MDT is meant to help target drug using offenders, instead it promotes the use of harder drugs such as heroin over cannabis. This is because heroin only stays in the system for 3 days compared to 14 days for cannabis, so is less likely to be detected. ${ }^{20,21,53}$ Figures showed that drug use in prisons has fallen over the years, cannabis fell by 59\% between $2003 / 04$ and 2013/14, positive tests of drugs has fallen by $64 \%$ over 10 years and Governments think drug use has fallen from $24.4 \%$ in $1996 / 97$ to $8.8 \%$ in $2006 / 07.2,6,47$ Although the number of needles seized in prisons in England and
Wales had increased $336 \%$ in a decade to 192 in 2013, Huesyin demonstrated how MDT should not be used as a reliable indicator and how it is encouraging inmates to use class A drugs such as heroin, which is injected. ${ }^{2,16}$ Drug testing on arrival to prison can identify drug users and requires the individual to attend 2 assessments, which lead to structured treatment and other recovery support. In areas operating drug testing on arrival, two thirds of those entering are identified following the initial drug test. ${ }^{54}$ It is thought that MDT is not effective, as $73 \%$ of those tested have never tested positive, nearly all $(98 \%)$ agreed that MDT encouraged people to use heroin and $69 \%$ of officers believed inmates cheat on urine tests. ${ }^{11,55}$ 
Table 3 shows that they do return a positive rate, whether it is a correct representation is unknown. Furthermore, synthetic cannabis is not detected using MDT and it is estimated the cost of MDT was equivalent to twice the cost of running a credible treatment and rehabilitation program, and equivalent to half of the healthcare budget for some prisons. ${ }^{9,36,40}$ Although $32 \%$ of inmates said the punishment for positive MDT's did deter them from using drugs. ${ }^{55}$

Table 3 The success of MDT tests in prisons in England andWales (2013/2014). Reconstructed from Drugs in Prison, The Centre for Social Justice ${ }^{6}$

\begin{tabular}{ll}
\hline Test type & Proportion returning a positive rate \\
\hline Suspicion & $30 \%$ \\
Reception & $24 \%$ \\
Frequent & $17 \%$ \\
Random & $7 \%$ \\
Risk & $5 \%$ \\
\hline
\end{tabular}

\section{Solutions}

A political will and intelligence based approach is necessary for drugs to be eliminated from prisons. The focus of interrupting the supply requires the need to keep up with drug trails throughout prisons; a better approach would be to eliminate the drug market. ${ }^{2,6}$ The UK Government have acknowledged that more needs to be done to control access to drugs in prisons, for example spending $£ 15$ million on new x-ray scanners that will be used to detect if prisoners, visitors or staff have drugs concealed under their clothes or inside body cavities. ${ }^{6,15}$ A prison service spokesperson announced that there was to be a major reorganisation of the prison system, including 2,500 extra prison officers together with new security measures in order to tackle drones, mobile telephones and drugs. This is expected to help make prisons places of safety and reform in the future..$^{56}$

New measures such as watchtowers for guards to spot drones and no-fly zones over prisons, with the aim of tackling the problem of drones dropping drugs and contraband into prison grounds, should also help..$^{57,58}$ Technology is being developed to detect drones and programme them so they cannot go to or over certain places. fFor example DroneShield, or technology developed by a German firm DeDrone's Drone Tracker. They have developed technology using a combination of acoustic, video, infrared and wireless signal detectors to spot incoming drones, see Figure 13; the system has been installed in German Federal prisons. ${ }^{58,59}$ Furthermore, the introduction of more prison drug dogs will help locate supplies in prison and on visitors. ${ }^{6,25,60}$ At HMP Wandsworth, the prison sniffer dog, see Figure 14 , found $£ 300,000$ worth of drugs in a year. ${ }^{30}$ There are two types of drug detection dogs in Australian prisons. Active dogs are allowed off the leash and are used to search property including buildings, hallways and perimeters. Passive dogs are managed by a handler and are used to search visitors and prisoners. ${ }^{36} \mathrm{~A}$ MoJ spokesperson said that the rise in drugs being seized did not mean the UK Government's prison strategies were failing, it meant the robust security measures including drug dogs and intelligence led searches were working. ${ }^{49}$ There needs to be more investment in prison sniffer dogs, as they are an effective means of locating drugs, but between 2010 and 2014, the number of prison dogs in England and Wales fell by $27 \%$ to $328 .{ }^{6}$

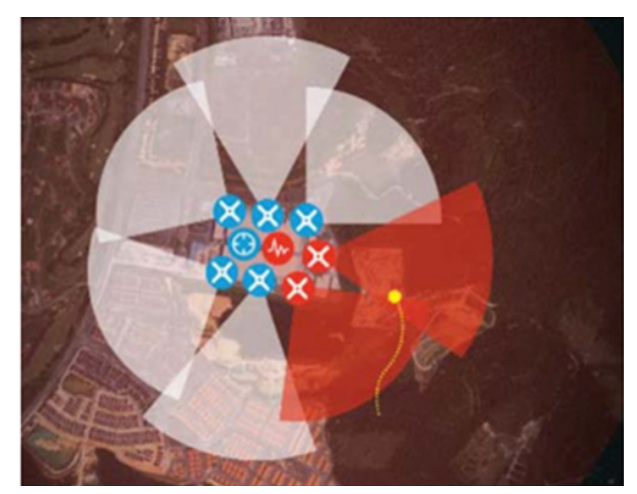

Figure 13 The technology has the ability to identify the make, model and capacity of the drone. The drone is visible as a yellow dot with a tail showing the path, which has flagged on the detection software in the red zones. ${ }^{59}$

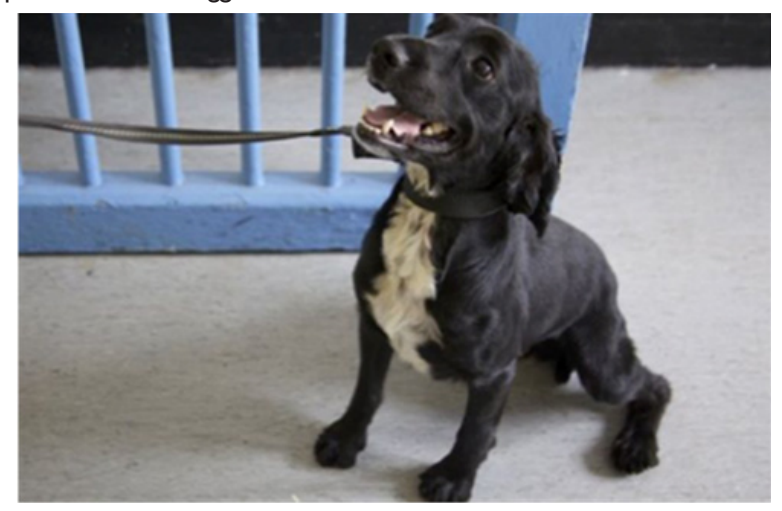

Figure I4 Prison sniffer dog in HMP Wands worth that found $£ 300,000$ worth of drugs in a year. ${ }^{30}$

It is thought that perimeter security is vital to prevent drugs entering prisons. In the US, regular guards should not be in control of prison gates and parking lots; this should be handled by the state police. ${ }^{22}$ If prisoners spent more time locked up than in exercise yards, and if windows were locked and barred at all, times it could limit the ways drugs enter prison. ${ }^{17}$ The need for increased security needs to be balanced with the needs of prisoners, allowing them to undertake activities and have the family relationships necessary to reduce the risk of reoffending. ${ }^{9}$ To completely stop or limit prison visits would be counterproductive and inhumane as they are an essential element of the rehabilitation process. ${ }^{3}$ To help reduce drugs entering prisons via visitors, the visits could take place in partitioned rooms with more intimate searches on all visitors. ${ }^{17} \mathrm{CSJ}$ warns that manual searches are not effective enough and the frequency should be increased..$^{15}$ The recommendations are that every prisoner entering prison, every visitor or open visit should be searched and 1 in 10 prison staff searched every month. ${ }^{6}$

The use of mobile phones has long been banned but enforcement measures are ineffective with more than 15,000 mobile phones and SIM cards removed from jails in a year. ${ }^{61}$ Inmates are constantly finding new ways, including decreasing the size of the mobile phone (Figure 15). to get them into prisons. ${ }^{62} \mathrm{New}$ powers will enable prison authorities to secure court orders requiring network providers to blacklist handsets and disconnect SIM cards. The new telecommunications restriction orders contained in the recent Serious Crime Act mean that governors no longer need to search for 
illicit mobile phones. ${ }^{61}$ The prison authorities can use routine phone surveillance systems to identify any devices being used. Former Chief Inspector David Ramsbottom said that installing technology that blocks all mobile phone use in prisons in England and Wales would be far simpler and more effective. It would cost $£ 30$ million to install and a further $£ 800,000$ a year to maintain and cannot be implemented in prisons with residential areas close by, whereas the restriction orders cost $£ 3.3$ million over 10 years. ${ }^{16,61}$

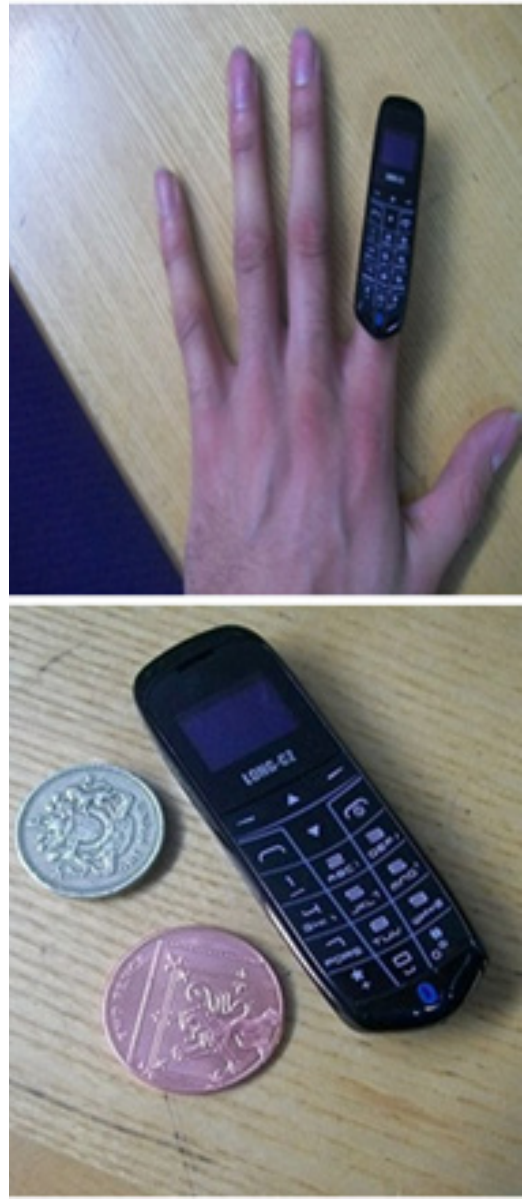

Figure I 5 Mini mobile phones are popular, they cost $£ 5$ and are small enough to be kept internally and are not detected by scanners. ${ }^{62}$

Without the use of illicit mobile phones, the trafficking of drugs into prison is difficult since there is a lack of communication with the community outside. Drug workers and the police are tackling reoffending by helping inmates, giving them access to help with life skills, education and training, employment, drug treatment and housing. ${ }^{54}$ The National Offender Management System and individual prisons have produced a wide range of education and information material to assist with the issues in prisons. This includes confidential assistance that should be available to friends and family members who may be pressured to help smuggle drugs into prisons, pay drug debts or are generally worried about the misuse of drugs by an inmate. ${ }^{3}$ The Integrated Drug Treatment System was developed with the aim of ensuring that drug users in prisons have access to the same quality treatment as those in the community, to try to break the link between drug use and criminal behaviour. ${ }^{63}$ The 2015 Ombudsman report advised that prison staff need to be more aware of synthetic cannabis and the signs that prisoners were taking them..$^{25}$
The effectiveness of methadone treatment programmes for drugmisusing offenders has been researched and the results summarised in Table $4{ }^{64,65}$ In all studies apart from one, it was found the treatment is effective in reducing criminal activity. Norwegian prisons strongly discourage the use of drugs in prison through sniffer dogs, daily cell inspections, MDT and body searches, which in turn mean prisoners, would rarely smuggle and store large quantities of drugs. ${ }^{46}$ In Danish prisons, prison drug treatment has been improved in both scale and variation. They offer substitution treatment, cannabis treatment, treatment wings and individual counselling. As well as using MDT on all prisoners, intensified searches and increased use of sniffer dogs, heavier fines are being enforced to implement the rules, for example, isolation cells and withdrawal of leave and parole. ${ }^{11}$

Table 4 Effectiveness of methadone treatments at reducing criminal activity Reconstructed from Holloway, Bennett et al ${ }^{64,65}$

\begin{tabular}{|c|c|c|c|c|}
\hline Author & Total $\mathbf{N}$ & Country & Intervention & Effective \\
\hline Bale et al. 1980 & 283 & USA & $\begin{array}{l}\text { Methadone } v \\
\text { no treatment }\end{array}$ & Yes \\
\hline Bell 1997 & 193 & Australia & $\begin{array}{l}\text { High dose } \\
\text { methadone v } \\
\text { low dose } \\
\text { methadone }\end{array}$ & Yes \\
\hline Gossop et al. 2003 & 418 & UK & $\begin{array}{l}\text { Methadone } v \\
\text { residential care }\end{array}$ & Yes \\
\hline $\begin{array}{l}\text { Gunne and } \\
\text { Gronbladh 1981 }\end{array}$ & 34 & Sweden & $\begin{array}{l}\text { Methadone } v \\
\text { no treatment }\end{array}$ & Yes \\
\hline Hubbard et al. 1997 & 3496 & USA & $\begin{array}{l}\text { Outpatient } \\
\text { methadone v } \\
\text { long-term } \\
\text { residential }\end{array}$ & Yes \\
\hline $\begin{array}{l}\text { Hutchinson et al. } \\
2000\end{array}$ & 107 & UK & $\begin{array}{l}\text { Continuous } \\
\text { methadone v } \\
\text { interrupted } \\
\text { methadone }\end{array}$ & Yes \\
\hline $\begin{array}{l}\text { Kosten and } \\
\text { Rounsaville } 1987\end{array}$ & 123 & USA & $\begin{array}{l}\text { Methadone } \\
\text { maintenance v } \\
\text { detoxification }\end{array}$ & No \\
\hline Magura et al. 1993 & 249 & USA & $\begin{array}{l}\text { Methadone } v \\
\text { 7-day heroin detox }\end{array}$ & Yes \\
\hline $\begin{array}{l}\text { McGlothin et al. } \\
\text { |98I }\end{array}$ & 207 & USA & $\begin{array}{l}\text { High dose } \\
\text { methadone v } \\
\text { low dose } \\
\text { methadone }\end{array}$ & Yes \\
\hline Simpson et al. 1982 & 1047 & USA & $\begin{array}{l}\text { Methadone } \\
\text { maintenance v } \\
\text { intake only }\end{array}$ & Yes \\
\hline Strang et al 2000 & 33 & UK & $\begin{array}{l}\text { Injected methadone } \\
\mathrm{v} \\
\text { oral methadone }\end{array}$ & Yes \\
\hline
\end{tabular}

In Canada, several measures are used to enforce their zero tolerance policy on drugs, including urine tests, sniffer dogs and electronic scanners that detect the slightest trace of drugs. However, not all institutions have access to the equipment. More worryingly the equipment is often available but defective, or staff are not trained 
how to use it. Prisoners who test positive or found with drugs can face disciplinary actions and lose privileges. Visitors are warned not to bring drugs into prison with the maximum penalty being $\$ 2,000$ or life imprisonment. ${ }^{60}$ In Canada, some prisons are draping nets over the perimeter fences to try to stop drones from being able to drop contraband and drugs and doubling their perimeter guards. ${ }^{58}$ In Ohio, inmates and staff are randomly tested using urine tests, sniffer dogs and phone monitoring to ensure the zero tolerance policy. Millions of dollars are spent on urine testing but it is only effective if there are consequences. It is critical to ensure prosecution of inmates and staff who try to introduce drugs into the prison or possess illegal substances. ${ }^{66}$

In Australia, effective intelligence gathering is carried out using wastewater analysis. It is also being trialled in USA and Spain and it allows an accurate measure of drug use in prison. ${ }^{6}$ It provides reliable, reproducible, objective and near real-time data and is a more economical and quick way that does not involve invading personal privacy ${ }^{67}$ A study was carried out in Catalonia, North East Spain that collected sewage samples from June 2008 to June 2009 on 42 occasions. The results are summarised in Table 5; there was a $100 \%$ detection rate for 8 out of 19 analytes tested ${ }^{67}$ The results showed a relatively stable consumption of methadone and alprazolam and an upward trend in the consumption of cannabis, cocaine and ephedrine. ${ }^{67}$

Table 5 Frequency of detection (\%) of illicit substances measured in the prison sewage waters. Reconstructed from Postigo, de Aldaet $\mathrm{al}^{7}$

\begin{tabular}{|c|c|c|}
\hline Chemical Class & Analyte & Frequency $(\%) n=42$ \\
\hline \multirow{3}{*}{ Cocainics } & Benzoylecgonine & 100 \\
\hline & Cocaine & 100 \\
\hline & Cocaethylene & 0 \\
\hline \multirow{3}{*}{ Cannabinoids } & $\mathrm{THC}-\mathrm{COOH}$ & 100 \\
\hline & $\mathrm{OH}-\mathrm{THC}$ & 0 \\
\hline & $\mathrm{THC}$ & 7 \\
\hline \multirow{5}{*}{ Opioids } & Methadone & 100 \\
\hline & EDDP & 100 \\
\hline & Morphine & 100 \\
\hline & 6acetylmorphine & 17 \\
\hline & Heroin & 5 \\
\hline \multirow{4}{*}{$\begin{array}{l}\text { Amphetamine-like } \\
\text { compounds }\end{array}$} & Ephedrine & 100 \\
\hline & MDMA & 19 \\
\hline & Amphetamine & 2 \\
\hline & Methamphetamine & 5 \\
\hline \multirow{3}{*}{ LSD and metabolies } & O-H-LSD & 5 \\
\hline & Nor-LSD & 0 \\
\hline & LSD & 12 \\
\hline Benzodiazepine & Alprazolam & 100 \\
\hline
\end{tabular}

\section{Conclusion}

This literature review confirms that drugs are a serious issue within prisons, both in the UK and Worldwide. It is evident that over the years Governments have tried different approaches to control drugs within prisons. However, from the research contained within this review it has become apparent that considerably more needs to be done going forward. The pattern of drug trends is continuously changing, as a result of both MDT and drug availability. With NPS such as spice and black mamba becoming more prominent in recent years, it is clear that Governments need to be able to keep up with the changes in order to be proactive with treatment and monitoring.

One of the most serious issues that currently needs addressing is corrupt prison staff that are responsible for transporting drugs and illegal contraband into prisons or just turning a blind eye to inmates behaviour. In an ideal world, the issues discussed earlier in this review regarding the use of drugs in prisons would be reduced, if not resolved, if all ways of trafficking drugs into prisons were eliminated, in turn this would make treatments more effective. Finally, the introduction of MDT, sniffer dogs and more effective searches are clearly a step in the right direction helping to solve the issues of drugs in prisons, these still have their limitations. It appears that prison authorities are spending vast amounts of time and money managing the issue of drugs in prisons, however this does not appear to be effective and more needs to be done by way of eradication.

\section{Acknowledgments}

None.

\section{Conflicts of interest}

The author declares there are no conflicts of interest.

\section{References}

1. Stöver H, Michels I. Drug use and opioid substitution treatment for prisoners. Harm Reduction Journal. 2010;7(17):1-7.

2. Djemil H. Inside Out: How to get drugs out of prisons. Centre for Policy Studies, Canada. 2008;1-37.

3. Woodall J. Social and environmental factors influencing in-prison drug use. Health Education. 2011;112(1):31-46.

4. Offender Management Statistics Bulletin, England and Wales. Ministry of Justice, USA, 2016;1-18.

5. Dolan K, Wirtz AL, Moazen B, et al. Global burden of HIV, viral hepatitis, and tuberculosis in prisoners and detainees. Lancet. 2016;388(10049):1089-1102.

6. Drugs in Prisons. The Centre for Social Justice, USA; 2015;1-86.

7. Michel L. Drug use in prisons: strategies for harm reduction (ANRSPRIDE Program). Cien Saude Colet. 2016;21(7):2081-2088.

8. Rao R, Mandal P, Gupta R, et al. Factors affecting drug use during incarceration: A cross-sectional study of opioid-dependent persons from India. J Subst Abuse Treat. 2016;61:13-17.

9. Changing patterns of substance misuse in adult prisons and service responses. Her Majesty's Inspectorate of Prisons, USA; 2015:1-85.

10. Prisons and drugs in Europe: The problem and responses. European monitoring centre for drugs and drug addiction, USA, 2012;1-36.

11. Kolind T. Drugs and discretionary power in prisons: The officer's perspective. Int J Drug Policy. 2015;26(9):799-807. 
12. Global Prison Trends 2015. Penal Reform International, USA; 2015:1-52.

13. Kolind T, Duke K. Drugs in prisons: exploring use, control, treatment and policy. drugs: education. Prevention and Policy. 2016; 3(2):89-92.

14. Rowell-Cunsolo T, Sampong S, Befus M, et al. Predictors of illicit drug use among prisoners. Subst Use Misuse. 2016;51(2): 261-267.

15. How drugs get into prisons in England and Wales. BBC, USA. 2015.

16. Godfrey W. How Inmates Smuggle Drugs into Jail: A Report from the Inside. The Fix. USA. 2011.

17. Drugs in prisons: Supply and remand. The Economist, USA. 2013.

18. Drug Wise: Cannabis. Drug Wise, USA. 2016

19. Boys A, Farrell M, Bebbington P, et al. Drug use and initiation in prison results from a national prison survey in England and Wales. Addiction. 2002;97(12):1551-1560.

20. Tompkins C. There's that many people selling it: Exploring the nature, organisation and maintenance of prison drug markets in England. Drugs: Education. Prevention and Policy. 2015;23(2):144-153.

21. Watson T. The elusive goal of drug-free prisons. Substance Use \& Misuse 2016;51(1):93-103.

22. Harris D. A prisoner reveals secrets about smuggling drugs into prison Prison Writers, USA. 2016

23. Crewe B. Prison drug dealing and the ethnographic lens. The Howard Journal of Criminal Justice. 2006;45(4):347-368.

24. The correctional aervice of canada admits to not having control over drug trafficking and drug use in canada's Prisons. Canada News Wire, PR Newswire Association LLC, USA; 2013.

25. Sample I. Synthetic cannabis 'having a devastating impact in UK prisons'. The Guardian, USA. 2016.

26. Drones seized over HMP Pentonville carrying drugs and phones. BBC, USA. 2016.

27. Mjåland K. Exploring prison drug use in the context of prison-based drug rehabilitation. Drugs: Education, Prevention and Policy. 2016;23(2):154 162.

28. Pharo J. Lags getting high on deadly drug 'spice' after it's sprayed onto kids' drawings. The Sun, USA. 2016.

29. McClatchy- Tribune Business News. Roumieh inmates, doctor and guards charged with drug trafficking. Tribune Content Agency LLC, USA; 2013

30. Thomas E, Titheradge N. Inside Wandsworth prison: Drugs and tension. BBC News, USA. 2016.

31. Samuel M. More than 40 prison guards indicted in Georgia on drug trafficking charges. NPR, USA. 2016.

32. Brown P, Ryan M. 'Staggering corruption': 46 correctional officers charged in years-long drug trafficking sting. CNN, USA. 2016.

33. McLellend E. Drug-smuggling gang ran $£ 30 \mathrm{~m}$ operation from prison cells using laptops. Mail Online, USA. 2016.

34. Kolind T, Frank V, Dahl H. Drug treatment or alleviating the negative consequences of imprisonment? A critical view of prison-based drug treatment in Denmark. Int J Drug Policy. 2010;21(1):43-48.

35. Prison: the facts. Prison Reform Trust, USA, 2016; p. 1-12.

36. Dolan K, Rodas A. Detection of drugs in Australian prisons: supply reduction strategies. Int J Prison Health. 2014;10(2):111-117.

37. Connor D, Tewksbury R. Inmates and prison involvement with drugs: examining drug-related misconduct during incarceration. Journal of Contemporary Criminal Justice. 2016;32(4):426-445.
38. Gray R. Blades, booze and drugs seized by Barlinnie staff. Evening Times, USA. 2014.

39. Reducing Drug Use, Reducing Reoffending. UK Drug Policy Commission, UK, 2008; p.1-8.

40. Gore S, Bird A. Cost implications of random mandatory drug tests in prisons. The Lancet. 1996;348(9035):1124-1127.

41. Belenko S, Peugh J. Estimating drug treatment needs among state prison inmates. Drug Alcohol Depend. 2005;77(3):269-281.

42. Bower Peterson C, Shepard D, Dailey M, et al. The cost-effectiveness of prison-based drug treatment. Corrections Compendium. 2011;36(4):1-6.

43. Stallwitz A, Stöver H.The impact of substitution treatment in prisons - A literature review. Int J Drug Policy. 2007;18(6):464-474.

44. Introducing Locally Funded Drug Testing on Arrest (and Associated Interventions). Home Office. USA, 2011; p. 1-24.

45. Adult Drug Statistics from the National Drug Treatment Monitoring System (NDTMS). Public Health England, UK, 2014; p. 1-38.

46. Mjaland K. A culture of sharing': Drug exchange in a Norwegian prison Punishment \& Society. 2014;16(3):336-352.

47. Minister Announces Latest Move in the Fight Against Drugs in Prisons CJP, USA. 2016.

48. Prison: the facts; Bromley Briefings Summer 2013. Prison Reform Trust USA, 2013; p. 1-12.

49. Johnston C. UK prison drug seizures on the rise, new figures show. The Guardian, USA. 2015

50. Travis A. Legal highs and prescription drugs face ban in English and Welsh prisons. The Guardian, USA. 2015.

51. Press Association. More than $1 \mathrm{~kg}$ of 'legal high' drugs seized at UK prison in one month. The Guardian, USA. 2016.

52. 2015 National Drug Threat Assessment Summary. U.S. Department of Justice Drug Enforcement Administration, USA, 2015; pp. 1-148.

53. Gore S, Bird A. Drugs in British Prisons. The BMJ. 1998;316(7140):12561257.

54. 2010 to 2015 Government policy: reoffending and rehabilitation. Ministry of Justice, USA. 2015

55. Ramsay M. Prisoners' drug use and treatment: seven research studies Home Office Research Study 267, USA, 2003;1-164.

56. Rahman-Jones I. Is it harder to smuggle drugs into high security prisons? BBC, USA. 2007

57. White C. Are prison officers smuggling drugs to prisoners? BBC Three, USA. 2016.

58. Burton L. Prison and Jail Officials Face New Challenge: Drones Used to Smuggle Contraband. Prison Legal News. 2016;27(9): 18-19.

59. O’Malley J. Keeping drones at bay [UAV control]. Engineering and Technology. 2017;11(6):32-35.

60. Crackdown has reduced drug-trafficking in prisons, officials content. The Gazette, USA. 2008.

61. Travis A. New powers to cut off illicit mobile phones used in prisons. The Guardian, USA. 2016.

62. Dunn J. Mini phones are bestsellers for inmates who store them internally. Mail Online, USA. 2016.

63. National treatment agency for substance misuse- prison based treatment for offenders. NHS, USA. 2017. 
64. Holloway K, Bennett T, Farrington D. The effectiveness of criminal justice and treatment programmes in reducing drug-related crime: a systematic review. Home Office, USA, 2008;1-9.

65. Roberts J, Hayes AJ, Carlisle J, et al. Review of drug and alcohol treatments in prison and community settings; A systematic review conducted on behalf of the prison health research network. The University of Manchester, USA, 2007;1-163.
66. Riveland C. Prison management trends, 1975-2025. Crime and Justice. 1999;26:163.

67. Postigo C, de Alda ML, Barceló D. Evaluation of drugs of abuse use and trends in a prison through wastewater analysis. Environ Int. 2011;37(1):49-55. 